\title{
Multinationals, Hedging, and Capital Structure under Exchange Rate Uncertainty*
}

\author{
Udo BROLL ${ }^{\dagger}$ \\ Dresden University of Technology \\ Kit Pong WONG $\ddagger$ \\ University of Hong Kong
}

April 2005

\begin{abstract}
This paper examines the interplay of the financing and hedging decisions of a risk-averse multinational firm having a wholly-owned foreign subsidiary. Exchange rate risk management of the multinational firm is shown to have direct impacts on its international capital structure decision and on its currency of denomination decision. If a currency forward market exists, the multinational firm will devise its international capital structure so as to minimize the global weighted average cost of capital. Or else the multinational firm has to rely on a money market hedge through issuing more foreign currency denominated debt and less domestic currency denominated debt, thereby resulting in a higher global weighted average cost of capital.
\end{abstract}

Key words: Multinationals; Hedging; Capital structure; Exchange rate uncertainty

JEL classification: D81; F23; G32

${ }^{*}$ We would like to thank Michele Fratianni, George Tavlas (the editor), and an anonymous referee for their helpful comments and suggestions. Wong gratefully acknowledges financial support from a grant provided by the University Grants Committee of the Hong Kong Special Administrative Region, China (Project No. AoE/H-05/99). The usual disclaimer applies.

${ }^{\dagger}$ Department of Business Management and Economics, Dresden University of Technology, 01062 Dresden, Germany. Tel.: (49)(351) 463-33230, fax: (49)(351) 463-37736, e-mail: broll@iwb-dresden.de (U. Broll).

${ }^{\ddagger}$ Corresponding author. School of Economics and Finance, University of Hong Kong, Pokfulam Road, Hong Kong. Tel.: (852) 2859-1044, fax: (852) 2548-1152, e-mail: kpwong@econ.hku.hk (K. P. Wong). 


\section{Multinationals, Hedging, and Capital Structure under Exchange Rate Uncertainty}

Key words: multinationals, hedging, capital structure, exchange rate uncertainty

JEL classification: D81, F23, G32

\section{Abstract}

This paper examines the interplay of the financing and hedging decisions of a risk-averse multinational firm having a wholly-owned foreign subsidiary. Exchange rate risk management of the multinational firm is shown to have direct impacts on its international capital structure decision and on its currency of denomination decision. If a currency forward market exists, the multinational firm will devise its international capital structure so as to minimize the global weighted average cost of capital. Or else the multinational firm has to rely on a money market hedge through issuing more foreign currency denominated debt and less domestic currency denominated debt, thereby resulting in a higher global weighted average cost of capital.

One of the major questions raised by multinational firms is how multiple currencies affect their capital structure choices (Hodder and Senbet, 1990; Giddy, 1994). Shapiro (1984) and Rhee, Chang, and Koveos (1985) refer to this question as the currency of denomination decision for debt financing. As documented by Keloharju and Niskanen (1997), multinational firms with exports constituting a significant fraction of turnover are most likely to raise foreign currency denominated debt, implying a strong hedging motive behind the currency of determination decision for debt financing.

The capital structure decision in an international setting may involve a rather complicated flow of funds between parent firms and foreign subsidiaries. For example, a foreign subsidiary may be funded by its retained earnings, by intra-firm debt or equity transfers from its parent, or by local borrowing. Similarly, a parent may be funded by its retained 
earnings, by new share issues, or by debt. To address the international capital structure decision in general and the currency of determination decision in particular, we present a single-period model of a multinational firm having a wholly-owned foreign subsidiary and facing exchange rate uncertainty. The model is enriched with the choice of currency for debt being an integral part of exchange rate risk management.

If the multinational firm is privately held and owner-managed, it is reasonable to assume risk-averse behavior. Even in the case that the multinational firm is publicly listed, managerial risk aversion (Stulz, 1984), corporate taxes (Smith and Stulz, 1985), costs of financial distress (Smith and Stulz, 1985), and capital market imperfections (Stulz, 1990; and Froot, Scharfstein, and Stein, 1993) all imply a concave objective function for the multinational firm. Thus, we use risk aversion as an approximation for these imperfections.

The results of this paper show how exchange rate movements, multiple tax jurisdictions, segmented capital markets, and currency forward markets jointly determine the optimal international capital structure and the best mix of currencies. If the risk-averse multinational firm has access to an unbiased currency forward market, we show that the firm will choose its international capital structure to minimize the global weighted average cost of capital. In this case, neither the attitude towards risk of the firm nor the incidence of exchange rate uncertainty play a role in determining the optimal mix of financing of the firm. In contrast, if the firm has no access to the currency forward market, we show that the firm has to rely on a money market hedge via issuing more foreign currency denominated debt and less domestic currency denominated debt. This hedging strategy results in a distortion that the global weighted average cost of capital exceeds the minimum level.

Elliott, Huffman, and Makar (2003) and Nguyen and Faff (2004) document that foreign currency denominated debt and foreign currency derivatives appear to be substitutes in hedging foreign currency risk for US multinational corporations and for Australian firms, respectively. Our model thus offers a theoretical rationale for their empirical findings.

The rest of this paper is organized as follows. We first develop a single-period model of a risk-averse multinational firm under exchange rate uncertainty. In Section 2, we charac- 
terize the multinational firm's optimal hedging decision when an unbiased currency forward market exists. Section 3 derives the firm's optimal international capital structure decision when the optimal currency forward hedge is in place. Section 4 examines the implications of exchange rate risk management on the international capital structure decision and on the currency of denomination decision. The final section offers some concluding remarks.

\section{The model}

Consider a risk-averse multinational firm that makes decisions in a single-period horizon with two dates, indexed by $t=0$ and 1 . The parent firm, domiciled in the home country, has a wholly-owned subsidiary located in a foreign country. At date 0, the parent requires a fixed investment, $I_{p}$, to generate a positive net end-of-period cash flow, $X_{p}$, where $I_{p}$ and $X_{p}$ are denominated in the domestic currency and $X_{p}>I_{p}$. Likewise, the subsidiary requires a fixed investment, $I_{s}$, to generate a positive net end-of-period cash flow, $X_{s}$, where $I_{s}$ and $X_{s}$ are denominated in the foreign currency and $X_{s}>I_{s}$.

Let $e_{t}$ be the spot exchange rate of the domestic currency against the foreign currency at date $t$. At date $0, e_{0}$ is revealed while $\tilde{e}_{1}$ is a positive random variable distributed according to a known probability density function. ${ }^{1}$ For simplicity, we assume that the spot exchange rate follows a random walk in that $e_{0}$ is the best predictor of $\tilde{e}_{1}$. That is, we set $e_{0}$ equal to the expected value of $\tilde{e}_{1}{ }^{2}$

To finance the required investment, $I_{s}$, the subsidiary relies on equity transfers from the parent, $E_{s}$, and debt issuance in the foreign capital market, $D_{s}$, yielding the following balance sheet:

$$
I_{s}=E_{s}+D_{s}
$$

\footnotetext{
${ }^{1}$ Throughout the paper, a tilde $(\sim)$ always signifies a random variable.

${ }^{2}$ This assumption, albeit inessential for our qualitative results, has strong theoretical and empirical justification (see Rogalski and Vinso, 1977; Roll, 1977; Meese and Rogoff, 1983; and Broll and Wong, 2002), especially over short horizons.
} 
The parent, on the other hand, raises the total funds needed, $I_{p}+e_{0} E_{s}$, by issuing debt, $D_{p}$, and equity, $E_{p}$, in the domestic capital market. The balance sheet of the parent is therefore given by

$$
I_{p}+e_{0} E_{s}=E_{p}+D_{p}
$$

Substituting equation (1) into equation (2) yields the consolidated global balance sheet of the multinational firm:

$$
I_{p}+e_{0} I_{s}=D_{p}+e_{0} D_{s}+E_{p}
$$

Hereafter, we denote $K=I_{p}+e_{0} I_{s}$ as the total investment made by the multinational firm in units of the domestic currency.

We assume that the domestic and foreign capital markets are segmented. This assumption is critical to the effect of the change in domestic for foreign debt on the multinational firm's cost of capital. Desai, Foley, and Hines (2004) empirically study the capital structure decision of foreign affiliates of US multinationals. They find that subsidiaries do alter the level and composition of debt in response to tax differences across countries, and that creditor rights and the development of the capital markets influence the capital structure choice. These results seem to support our assumption that capital markets are somewhat segmented.

Interest costs of debt, be they denominated in the domestic currency or in the foreign currency, are assumed to comprise default risk premia that are positively related to debtequity ratios. Due to a lack of bargaining power, the subsidiary is confronted with a pre-specified interest rate schedule, $r_{s}\left(\lambda_{s}\right)$, where $\lambda_{s}=D_{s} / E_{s}$ is the debt-equity ratio of the subsidiary. The parent, also lacking in bargaining power, faces a pre-specified interest rate schedule, $r_{p}\left(\lambda_{p}\right)$, where $\lambda_{p}=\left(D_{p}+e_{0} D_{s}\right) / E_{p}$ is the global debt-equity ratio, reflecting the fact that the subsidiary is wholly-owned by the parent. We assume that $r_{p}$ and $r_{s}$ are twice continuously differentiable functions that are strictly increasing and weakly convex. ${ }^{3}$

\footnotetext{
${ }^{3}$ This assumption is consistent with the static trade-off theory of capital structure. See, e.g., Kraus and Litzenberger (1973), Scott (1976), Brealey and Myers (2004), and Ross, Westerfield, and Jordon (2004).
} 
Interest costs of debt are fully tax-deductible in the home and foreign countries.

At date 1, the subsidiary has to pay corporate income taxes to the foreign government at a constant tax rate, $t_{s}$. The after-tax earnings, net of the debt repayments, of the subsidiary are given by

$$
Y_{s}=X_{s}-t_{s}\left(X_{s}-r_{s} D_{s}\right)-\left(1+r_{s}\right) D_{s}
$$

The subsidiary repatriates the entire amount of $Y_{s}$ to the parent through a liquidating dividend.

Since the dividend received from the subsidiary is denominated in the foreign currency, the parent is inevitably subject to exchange rate risk. To hedge its risk exposure, the parent sells $H$ units of the foreign currency forward in a currency forward market. Since we are interested in the economic implications of exchange rate risk management on the international capital structure decision and the currency of denomination decision, it suffices to restrict our attention to the case where the currency forward market is unbiased. Given the random walk model of the spot exchange rate, the unbiasedness of the currency forward market is tantamount to setting the forward exchange rate equal to $e_{0}$.

At date 1, the parent has to pay corporate income taxes on both domestic and foreign source income to the home government at a constant tax rate, $t_{p}$. The tax system in the home country, similar to that in the United States, allows credits for foreign taxes paid directly on income as it is received by the parent (direct credits) and for foreign income taxes paid on the income out of which a distribution is made to the parent (deemed paid or indirect credits). ${ }^{4}$ The amount of credits available on dividend remittances is limited to the home country tax liability on foreign source income. Firms are in excess credits if foreign tax payments exceed the limitation. Otherwise, firms for which the limitation is not binding receive full credits for taxes paid abroad and are said to be in excess limitation or deficit credits.

Let $\delta$ be the value of one dollar of dividend repatriations after home and foreign country

\footnotetext{
${ }^{4}$ For more details about foreign tax credits, see Hartman (1985), Scholes and Wolfson (1992), Altshuler and Fulghieri (1994), and Chowdhry and Coval (1998).
} 
taxes. Firms in excess credits pay no home country taxes on dividend repatriations so that one dollar of dividends is subject only to withholding taxes at a constant rate, $t_{w}$, paid to the foreign country, resulting in $\delta=1-t_{w}$. In contrast, firms in excess limitation must pay home country taxes on grossed up dividend repatriations but receives full credits on withholding taxes, thereby yielding $\delta=\left(1-t_{p}\right) /\left(1-t_{s}\right)$.

The after-tax earnings, net of the debt repayments, of the parent are given by

$$
\tilde{Y}_{p}=X_{p}+\left(e_{0}-\tilde{e}_{1}\right) H+\delta \tilde{e}_{1} Y_{s}-t_{p}\left[X_{p}+\left(e_{0}-\tilde{e}_{1}\right) H-r_{p} D_{p}\right]-\left(1+r_{p}\right) D_{p}
$$

The parent pays out the entire amount of $Y_{p}$ to the shareholders as a liquidating dividend. Shareholders of the parent have initial wealth, $W_{0}$, upon which $E_{p}$ is contributed to the parent as equity capital and the rest, $W_{0}-E_{p}$, is invested in riskless assets earning a rate of return, $r_{e}$. Thus, the end-of-period wealth of the shareholders can be written as

$$
\tilde{W}=\tilde{Y}_{p}+\left(1+r_{e}\right)\left(W_{0}-E_{p}\right)
$$

The after-tax cost of domestic currency denominated debt is given by $\left(1-t_{p}\right) r_{p}$. The after-tax cost of foreign currency denominated debt, on the other hand, consists of two components. The first component is $\left(1-t_{s}\right) r_{s}$, which is due to the interest cost. The second component arises from the fact that the after-tax value of one dollar of dividend repatriations is only $\delta$, implying that $1-\delta$ serves as an effective tax rate on dividend remittances. Inspection of equation (4) reveals a saving of $(1-\delta)\left[1+\left(1-t_{s}\right) r_{s}\right]$ on these taxes per dollar of foreign currency denominated debt. Thus, the after-tax cost of foreign currency denominated debt, which is the sum of these two components, can be written as $\delta\left(1-t_{s}\right) r_{s}-(1-\delta)$. The global weighted average cost of capital (WACC) of the multinational firm, $r_{k}$, is therefore defined by

$$
r_{k}=\left(1-t_{p}\right) r_{p} \frac{D_{p}}{K}+\left[\delta\left(1-t_{s}\right) r_{s}-(1-\delta)\right] \frac{e_{0} D_{s}}{K}+r_{e} \frac{E_{p}}{K}
$$

The multinational firm possesses a von Neumann-Morgenstern utility function, $U(W)$, defined over the date 1 wealth of its shareholders, $W$, with $U^{\prime}(W)>0$ and $U^{\prime \prime}(W)<0$, 
indicating the presence of risk aversion. The international capital structure of the multinational firm is a quadruple, $\left(D_{p}, D_{s}, E_{p}, E_{s}\right)$, that, using equations (1) and (2), reduces to a pair, $\left(D_{p}, D_{s}\right)$. Substituting equations $(3),(4),(5)$, and (7) into equation (6) yields

$$
\begin{aligned}
\tilde{W}= & \left(1-t_{p}\right)\left[X_{p}+\left(e_{0}-\tilde{e}_{1}\right) H\right]+\delta\left(1-t_{s}\right) \tilde{e}_{1} X_{s}-\left(1+r_{k}\right) K \\
& +\delta\left(e_{0}-\tilde{e}_{1}\right)\left[1+\left(1-t_{s}\right) r_{s}\right] D_{s}+\left(1+r_{e}\right) W_{0} .
\end{aligned}
$$

The decision problem of the multinational firm is to choose an international capital structure, $\left(D_{p}, D_{s}\right)$, and a position in the currency forward market, $H$, so as to maximize the expected utility of the date 1 wealth of its shareholders:

$$
\max _{D_{p}, D_{s}, H} \mathrm{E}[U(\tilde{W})]
$$

where $\mathrm{E}(\cdot)$ is the expectation operator and $\tilde{W}$ is defined in equation (8).

\section{Optimal currency forward hedging}

To facilitate the analysis, we reformulate problem (9) as a two-stage optimization problem. In the first stage, we derive the hedging demand:

$$
H\left(D_{p}, D_{s}\right)=\arg \max _{H} \mathrm{E}[U(\tilde{W})]
$$

for any given international capital structure, $\left(D_{p}, D_{s}\right)$. Based on equation (10), we define

the indirect expected utility, $V\left(D_{p}, D_{s}\right)$, as $\mathrm{E}[U(\tilde{W})]$ evaluated at $H\left(D_{p}, D_{s}\right)$. In the second stage, we derive the optimal international capital structure:

$$
\left(D_{p}^{*}, D_{s}^{*}\right)=\arg \max _{\left(D_{p}, D_{s}\right)} V\left(D_{p}, D_{s}\right)
$$

Substituting equation (11) into equation (10) yields the optimal forward position, $H^{*}=$ $H\left(D_{p}^{*}, D_{s}^{*}\right)$, which completes the solution to problem (9). 
Using equation (10), $H\left(D_{p}, D_{s}\right)$ is defined by the following first-order condition:

$$
\mathrm{E}\left[U^{\prime}(\tilde{W})\left(e_{0}-\tilde{e}_{1}\right)\right]\left(1-t_{p}\right)=0
$$

The second-order condition is satisfied trivially given risk aversion. Using the covariance operator, $\operatorname{Cov}(\cdot, \cdot)$, equation $(12)$ can be written $\operatorname{as}^{5}$

$$
\mathrm{E}\left[U^{\prime}(\tilde{W})\right]\left[e_{0}-\mathrm{E}\left(\tilde{e}_{1}\right)\right]=\operatorname{Cov}\left[U^{\prime}(\tilde{W}), \tilde{e}_{1}\right] .
$$

Since the currency forward market is unbiased in that $e_{0}=\mathrm{E}\left(\tilde{e}_{1}\right)$, equation (13) reduces to

$$
\operatorname{Cov}\left[U^{\prime}(\tilde{W}), \tilde{e}_{1}\right]=0
$$

Based on equation (14), we can establish the following proposition.

Proposition 1. In the presence of the unbiased currency forward market, the hedging demand is $H\left(D_{p}, D_{s}\right)$ is given by

$$
H\left(D_{p}, D_{s}\right)=\frac{\delta}{1-t_{p}}\left\{\left(1-t_{s}\right) X_{s}-\left[1+\left(1-t_{s}\right) r_{s}\right] D_{s}\right\}
$$

for any given international capital structure, $\left(D_{p}, D_{s}\right)$.

Proof: Rewrite equation (8) as

$$
\begin{aligned}
\tilde{W}= & \left(1-t_{p}\right) X_{p}+\delta\left(1-t_{s}\right) e_{0} X_{s}-\left(1+r_{k}\right) K+\left(1+r_{e}\right) W_{0} \\
& +\left(e_{0}-\tilde{e}_{1}\right)\left\{\left(1-t_{p}\right) H+\delta\left[1+\left(1-t_{s}\right) r_{s}\right] D_{s}-\delta\left(1-t_{s}\right) X_{s}\right\} .
\end{aligned}
$$

Inspection of equations (14) and (16) reveals equation (15).

Proposition 1 implies that the optimal position of the multinational firm in the unbiased currency forward market is a full-hedge that completely removes its exchange rate risk exposure. This result is analogous to the celebrated full-hedging theorem derived by Danthine

\footnotetext{
${ }^{5}$ For any two random variables, $\tilde{x}$ and $\tilde{y}, \operatorname{Cov}(\tilde{x}, \tilde{y})=\mathrm{E}(\tilde{x} \tilde{y})-\mathrm{E}(\tilde{x}) \mathrm{E}(\tilde{y})$.
} 
(1978), Holthausen (1979), Katz and Paroush (1979), Broll and Zilcha (1992), Broll and Wong (1999), Broll, Wong, and Zilcha (1999), among others, in the hedging literature. The intuition underlying Proposition 1 is that the unbiased currency forward market essentially provides the multinational firm 'insurance' at actuarial terms, rendering full hedging by the firm optimal.

\section{Optimal international capital structure}

Now, we are ready to fully solve problem (9). It follows from Proposition 1 that no residual exchange rate risk remains. Thus, the second-stage optimization problem reduces to

$$
\max _{D_{p}, D_{s}} U\left[\left(1-t_{p}\right) X_{p}+\delta\left(1-t_{s}\right) e_{0} X_{s}-\left(1+r_{k}\right) K+\left(1+r_{e}\right) W_{0}\right]
$$

Since only the global WACC, $r_{k}$, in the objective function of program (17) depends on $D_{p}$ and $D_{s}$, the following proposition is immediately invoked. ${ }^{6}$

Proposition 2. In the presence of the unbiased currency forward market, the optimal international capital structure of the multinational firm minimizes the global WACC.

Proposition 2 implies that the optimal international capital structure of the multinational firm depends neither on its risk attitude nor on the incidence of the exchange rate uncertainty. This result is analogous to the celebrated separation theorem derived by Danthine (1978), Holthausen (1979), Katz and Paroush (1979), Broll and Zilcha (1992), Broll, Wong, and Zilcha (1999), among others, in the hedging literature. To see the intuition, inspection of equation (16) reveals that the exchange rate risk exposure of the multinational firm is entirely controlled by its forward position in the currency forward market and is totally unrelated to its international capital structure decision, thereby yielding the separation result.

\footnotetext{
${ }^{6}$ It is straightforward, albeit tedious, to show that the second-order conditions for a minimum are satisfied given the assumed properties of $r_{p}$ and $r_{s}$.
} 


\section{The effect of hedging on international capital structure}

In this section, we want to examine the implications of exchange rate risk management on the international capital structure decision and on the currency of denomination decision. It is of interest to see what role the currency forward market plays in the behavior of the multinational firm. To this end, we write the date 1 exchange rate as $\tilde{e}_{1}=e_{0}+\gamma \tilde{z}$, where $\gamma$ is a parameter taking a value of unity and $\tilde{z}$ is a zero-mean random variable.

If the currency forward market is either absent or not accessible by the multinational firm, the decision problem of the firm becomes

$$
\max _{D_{p}, D_{s}} \mathrm{E}[U(\tilde{W})] \quad \text { s.t. } \quad H \equiv 0
$$

where $\tilde{W}$ is defined in equation (8). The first-order conditions of problem (18) are given by

$$
\begin{aligned}
& \mathrm{E}\left[U^{\prime}(\tilde{W})\right]\left(-\frac{\partial r_{k}}{\partial D_{p}} K\right)=0, \\
& \mathrm{E}\left\{U^{\prime}(\tilde{W})\left\{-\frac{\partial r_{k}}{\partial D_{s}} K-\delta \gamma \tilde{z}\left[1+\left(1-t_{s}\right)\left(r_{s}+r_{s}^{\prime} \frac{\partial \lambda_{s}}{\partial D_{s}} D_{s}\right)\right]\right\}\right\}=0,
\end{aligned}
$$

The second-order conditions of problem (18) are satisfied given risk aversion and the assumed properties of $r_{p}$ and $r_{s}$.

Let $\left(D_{p}^{0}, D_{s}^{0}\right)$ be the optimal international capital structure in this case (i.e., $\gamma=1$ ). Using Propositions 1 and 2, we know that the solution of problem (18) would have been $\left(D_{p}^{*}, D_{s}^{*}\right)$ had $\gamma$ equaled zero. Hence, to compare $\left(D_{p}^{*}, D_{s}^{*}\right)$ and $\left(D_{p}^{0}, D_{s}^{0}\right)$, we can simply conduct the comparative static exercise with respect to the shift parameter, $\gamma$. According to Arrow (1965) and Pratt (1964), we can define a measure of absolute risk aversion of the multinational firm as $R(W)=-U^{\prime \prime}(W) / U^{\prime}(W)$ for any given $W$. We state the following proposition where a proof can be found in Appendix.

Proposition 3. If the preference of the multinational firm exhibits CARA or DARA, then the introduction of the unbiased currency forward market induces the firm to issue more domestic currency denominated debt and less foreign currency denominated debt. 
Proof: See Appendix.

Proposition 3 is a rather intuitive result. When the currency forward market is not accessible to the multinational firm, the only alternative to such a direct hedging is a money market hedge via issuing more foreign currency denominated debt and less domestic currency denominated debt. It follows immediately from Proposition 1 that the global WACC has to be distorted in a way that it exceeds the minimum attainable level in the presence of the unbiased currency forward market.

Elliott, Huffman, and Makar (2003) document that foreign currency denominated debt and foreign currency derivatives appear to be substitutes in hedging foreign currency risk for US multinational corporations. This finding is further confirmed by Nguyen and Faff (2004) using a sample of Australian firms. Proposition 3 thus offers a theoretical rationale for these empirical findings.

\section{Concluding remarks}

This paper has investigated the interaction between the financing and hedging decisions of a multinational firm facing exchange rate uncertainty. The results have shown how exchange rate movements, multiple tax jurisdictions, segmented capital markets, and currency forward markets jointly determine the optimal international capital structure and the best mix of currencies. If the multinational firm has access to an unbiased currency forward market, we have shown that the firm will choose its international capital structure to minimize the global weighted average cost of capital (WACC). In contrast, if the firm has no access to the currency forward market, we have shown that the firm has to rely on a money market hedge via issuing more foreign currency denominated debt and less domestic currency denominated debt, resulting in a distorted global WACC that exceeds the minimum level. 


\section{Appendix}

Proof of Proposition 3: We write the first-order conditions, equations (19) and (20), as

$$
\begin{aligned}
& V_{p}=-\mathrm{E}\left[U^{\prime}(\tilde{W})\right] \frac{\partial r_{k}}{\partial D_{p}} K=0, \\
& V_{s}=-\mathrm{E}\left[U^{\prime}(\tilde{W}) \tilde{M}\right]=0
\end{aligned}
$$

where

$$
\tilde{M}=\frac{\partial r_{k}}{\partial D_{s}} K+\delta \gamma \tilde{z}\left[1+\left(1-t_{s}\right)\left(r_{s}+r_{s}^{\prime} \frac{\partial \lambda_{s}}{\partial D_{s}} D_{s}\right)\right]
$$

The second-order conditions of problem (18) require that $V_{p p}<0, V_{s s}<0$, and $V_{p p} V_{s s}-$ $V_{p s}^{2}>0$, where

$$
\begin{aligned}
& V_{p p}=-\mathrm{E}\left[U^{\prime}(\tilde{W})\right] \frac{\partial^{2} r_{k}}{\partial D_{p}^{2}} K, \\
& V_{s s}=\mathrm{E}\left[U^{\prime \prime}(\tilde{W}) \tilde{M}^{2}\right]-\mathrm{E}\left[U^{\prime}(\tilde{W}) \frac{\partial \tilde{M}}{\partial D_{s}}\right], \\
& V_{p s}=-\mathrm{E}\left[U^{\prime}(\tilde{W})\right] \frac{\partial^{2} r_{k}}{\partial D_{p} \partial D_{s}} K .
\end{aligned}
$$

Given the assumed properties of $r_{p}$ and $r_{s}$, it is easily verified that $\partial^{2} r_{k} / \partial D_{p} \partial D_{s}>0$ and thereby $V_{p s}<0$.

We totally differentiate equations (A.1) and (A.2) with respect to $\gamma$ and apply Cramer's rule to yield

$$
\begin{aligned}
\frac{\mathrm{d} D_{p}}{\mathrm{~d} \gamma} & =\frac{V_{s \gamma} V_{p s}-V_{p \gamma} V_{s s}}{V_{p p} V_{s s}-V_{p s}^{2}}, \\
\frac{\mathrm{d} D_{s}}{\mathrm{~d} \gamma} & =\frac{V_{p \gamma} V_{p s}-V_{s \gamma} V_{p p}}{V_{p p} V_{s s}-V_{p s}^{2}}
\end{aligned}
$$

where $V_{p \gamma}=0$ and

$$
V_{s \gamma}=-\mathrm{E}\left[U^{\prime}(\tilde{W}) \tilde{z}\right] \delta\left[1+\left(1-t_{s}\right)\left(r_{s}+r_{s}^{\prime} \frac{\partial \lambda_{s}}{\partial D_{s}} D_{s}\right)\right]-\mathrm{E}\left[U^{\prime \prime}(\tilde{W}) \tilde{M} \tilde{z}\right] \delta Y_{s}
$$


Since $V_{p p}<0, V_{p s}<0$, and $V_{p p} V_{s s}-V_{p s}^{2}>0$, the sign of $\mathrm{d} D_{p} / \mathrm{d} \gamma$ will be opposite to that of $V_{s \gamma}$ while the sign of $\mathrm{d} D_{s} / \mathrm{d} \gamma$ will be the same as that of $V_{s \gamma}$.

Note that $\mathrm{E}\left[U^{\prime}(\tilde{W}) \tilde{z}\right]=\operatorname{Cov}\left[U^{\prime}(\tilde{W}), \tilde{z}\right]<0$ since $\partial U^{\prime}(W) / \partial z=U^{\prime \prime}(W) \delta \gamma Y_{s}<0$ under risk aversion. Thus, the first term in the right-hand side of equation (A.7) is positive. Using equation (A.3), we can write the second term in the right-hand side of equation (A.7) as

$$
\frac{Y_{s}}{\gamma\left[1+\left(1-t_{s}\right)\left(r_{s}+r_{s}^{\prime} \frac{\partial \lambda_{s}}{\partial D_{s}} D_{s}\right)\right]}\left\{\mathrm{E}\left[U^{\prime \prime}(\tilde{W}) \tilde{M}\right] \frac{\partial r_{k}}{\partial D_{s}} K-\mathrm{E}\left[U^{\prime \prime}(\tilde{W}) \tilde{M}^{2}\right]\right\}
$$

The second term in the curly brackets of expression (A.8) is clearly positive under risk aversion. If we can show that the first term is non-negative, then we can conclude that $V_{s \gamma}>0$. From equation (A.2) and the fact that $\mathrm{E}\left[U^{\prime}(\tilde{W}) \tilde{z}\right]<0$, we have $\partial r_{k} / \partial D_{s}>0$. Thus, the first term of expression (A.8) being non-negative is tantamount to $\mathrm{E}\left[U^{\prime \prime}(\tilde{W}) \tilde{M}\right] \geq$ 0 . Unfortunately, this term is a priori indeterminate without further restrictions on the preference of the multinational firm.

Using the Arrow-Pratt measure of absolute risk aversion, we have

$$
\mathrm{E}\left[U^{\prime \prime}(\tilde{W}) \tilde{M}\right]=-\mathrm{E}\left\{[R(\tilde{W})-R(\hat{W})] U^{\prime}(\tilde{W}) \tilde{M}\right\}
$$

where we have used equation (A.2), and $\hat{W}$ is the realized wealth level at which $\tilde{M}$ equals zero. If $U$ exhibits constant absolute risk aversion (CARA), then $R(W)$ is invariant to $W$ so that equation (A.9) implies that $\mathrm{E}\left[U^{\prime \prime}(\tilde{W}) \tilde{M}\right]=0$. On the other hand, if $U$ exhibits decreasing absolute risk aversion (DARA), then $R^{\prime}(W)<0$. Since both $\tilde{W}$ and $\tilde{M}$ are increasing in $\tilde{z}$, the sign of $R(\tilde{W})-R(\hat{W})$ must be opposite to that of $\tilde{M}$ under DARA. From equation (A.9), we have $\mathrm{E}\left[U^{\prime \prime}(\tilde{W}) \tilde{M}\right]>0$.

\section{References}

Altshuler, R. and P. Fulghieri (1994) "Incentive Effects of Foreign Tax Credits on Multinational Corporations." National Tax Journal 27:349-361.

Arrow, K.J. (1965) Aspects of the Theory of Risk-Bearing. Helsinki: Yrjo Jahnsson Saatio.

Brealey, R.A. and S.C. Myers (2004) Principles of Corporate Finance, 7th edition. New York, NY: McGraw-Hill. 
Broll, U. and K.P. Wong (1999) "Hedging with Mismatched Currencies." Journal of Futures Markets 19:859-875.

Broll, U. and K.P. Wong (2002) "Imperfect Forward Markets and Hedging." Economic Notes 31:143-154.

Broll, U., K.P. Wong, and I. Zilcha (1999) "Multiple Currencies and Hedging." Economica $66: 421-432$.

Broll, U. and I. Zilcha (1992) "Exchange Rate Uncertainty, Futures Markets and the Multinational Firm." European Economic Review 36:815-826.

Chowdhry, B. and J.D. Coval (1998) "Internal Financing of Multinational Subsidiaries: Debt vs. Equity." Journal of Corporate Finance 4:87-106.

Danthine, J.-P. (1978) "Information, Futures Prices, and Stabilizing Speculation." Journal of Economic Theory 19:79-98.

Desai, M.A., C.F. Foley, and J.R. Hines (2004) "A Multinational Perspective on Capital Structure Choice and Internal Capital Markets." Journal of Finance 59:2451-2487.

Elliott, W.B., S.P. Huffman, and S.D. Makar (2003) "Foreign-Denominated Debt and Foreign Currency Derivatives: Complements or Substitutes in Hedging Foreign Currency Risk?" Journal of Multinational Financial Management 13:123-139.

Froot, K.A., D.S. Scharfstein, and J.C. Stein (1993) "Risk Management: Coordinating Corporate Investment and Financing Policies." Journal of Finance 48:1629-1658.

Giddy, I.H. (1994) Global Financial Markets. Lexington, MA: D.C. Heath and Company.

Hartman, D.G. (1985) "Tax Policy and Foreign Direct Investment." Journal of Public Economics 26:107-121.

Hodder, J.E. and L.W. Senbet (1990) "International Capital Structure Equilibrium." Journal of Finance 45:1495-1516.

Holthausen, D.M. (1979) "Hedging and the Competitive Firm under Price Uncertainty." American Economic Review 69:989-995.

Katz, E. and J. Paroush (1979) "The Effect of Forward Markets on Exporting Firms." Economics Letters 4:272-274.

Keloharju, M. and M. Niskanen (1997) "Why Do Firms Raise Foreign Currency Denominated Debt?" Working paper, Helsinki School of Economics and Business Administration. 
Kraus, A. and R.H. Litzenberger (1973) "A State Preference Model of Optimal Financial Leverage." Journal of Finance 28:911-921.

Meese, R. and K. Rogoff (1983) "Empirical Exchange Rate Models of the Seventies: Do They Fit Out-of-Sample?" Journal of International Economics 14:3-24.

Nguyen, H. and R. Faff (2004) "Foreign Debt and Financial Hedging: Evidence from Australia." International Review of Economics and Finance, in press.

Pratt, J.W. (1964) "Risk Aversion in the Small and in the Large." Econometrica 32:122136.

Rhee, S.G., R.P. Chang, and P.E. Koveos (1985) "The Currency-of-Denomination Decision for Debt Financing." Journal of International Business Studies 16:143-150.

Rogalski, R.J. and J.D. Vinso (1977) "Stock Returns, Money Supply and the Direction of Causality." Journal of Finance 32:1017-1030.

Roll, R. (1977) "Violations of PPP and Their Implications for Efficient International Commodity Markets." In M. Sarnat and G.P. Szego, eds., International Finance and Trade 1:133-176.

Ross, S.A., R.W. Westerfield, and B.D. Jordan (2004) Fundamentals of Corporate Finance, 6th edition. Boston, MA: Irwin/McGraw-Hill.

Scholes, M.S. and M.A. Wolfson (1992) Taxes and Business Strategy: A Planning Approach. Englewood Cliffs, NJ: Prentice Hall.

Scott, J.H. (1976) "A Theory of Optimal Capital Structure." Bell Journal of Economics and Management Science 7:33-54.

Shapiro, A.C. (1984) "The Impact of Taxation on the Currency of Determination Decision for Long-Term Foreign Borrowing and Lending." Journal of International Business Studies 15:15-25.

Smith, C.W. and R.M. Stulz (1985) "The Determinants of Firms' Hedging Policies." Journal of Financial and Quantitative Analysis 20:391-405.

Stulz, R.M. (1984) "Optimal Hedging Policies." Journal of Financial and Quantitative Analysis 19:127-140.

Stulz, R.M. (1990) "Managerial Discretion and Optimal Financial Policies." Journal of Financial Economics 26:3-27. 